\title{
A SUITABLE PROCEDURE TO CHOOSE ANTIMICROBIALS AS CONTROLLING AGENTS IN FERMENTATIONS PERFORMED BY BACTERIA
}

\author{
Romulo C. Oliveira ${ }^{\text {; }}$ José G.C. Gomez ${ }^{1}$; Bayardo B. Torres²; Celso L. Bueno Netto'; Luiziana F. da Silva ${ }^{1 *}$ \\ ${ }^{1}$ Instituto de Pesquisas Tecnológicas do Estado de São Paulo S.A. - IPT, São Paulo, SP, Brasil; ${ }^{2}$ Departamento de Bioquímica, \\ Instituto de Química, Universidade de São Paulo, São Paulo, SP, Brasil
}

Submitted: January 19, 1999; Returned to authors for corrections: June 30, 1999; Approved: March 28, 2000

\section{SHORT COMMUNICATION}

\begin{abstract}
This work evaluated the influence of nitrofurantoin, erythromycin and streptomycin at 50, 25 and $12,5 \%$ of the minimal inhibitory concentration (MIC) on maximum specific growth rate $\left(\mu_{\mathrm{mx}}\right)$ and specific polymer accumulation rate $\left(\mu_{\mathrm{PHB}}\right)$ of Alcaligenes eutrophus, considered resistant to those antimicrobials. Nitrofurantoin strongly affected $\mu_{\max }$ even at $50 \%$ MIC. Streptomycin moderately affected $\mu_{\max }$ only at $50 \% \mathrm{MIC}$. Nitrofurantoin showed the most harmful effect on $\mu_{\mathrm{PHB}}$ when $50 \%$ MIC was applied and erythromycin was not harmful.
\end{abstract}

Key words: antimicrobial susceptibility, MIC, PHB, Alcaligenes eutrophus, Ralstonia eutropha

Procedures usually indicated to prevent contamination on fermentative processes include sterilization of equipment and medium, careful manipulation during inocula preparation, bacterial cultivation and product formation. Since sterilization and prevention of contamination in large scale processes are expensive, energy- and time-consuming, additional procedures would be useful to eliminate contaminants, such as the use of antimicrobials $(2,10)$. Choosing an antimicrobial with the desirable selective toxicity is difficult and the exact amount to be applied must be previously determined since an excessive concentration may modify the global performance of the microorganism of interest or remain in the product altering its properties.

Though many reports can be found on antibiotic susceptibility of Alcaligenes species of medical interest, there are not references about $A$. eutrophus (1) used in the production of polyhydroxybutyric acid (P3HB). $\mathrm{P} 3 \mathrm{HB}$ and its copolymer poly-(3-hydroxybutyric acid-co-3-hydroxyvaleric acid) (P3HB$c o-3 \mathrm{HV})$ have attracted great industrial attention as biodegradable plastics (8). They are generally produced in two steps: the first one aims at reaching high density of A. eutrophus cells and the second one at accumulation of large amounts of P3HB (4). Bacterial contamination may occur in both steps as the medium usually does not contain antimicrobial agents and large batches of fermentation may therefore be lost $(5,9)$.

In this work three antimicrobial agents were tested at subMIC concentrations regarding to their effects on kinetics of growth and $\mathrm{P} 3 \mathrm{HB}$ accumulation by A. eutrophus.

A. eutrophus DSM 545 (recently reclassified as Ralstonia eutropha) was submitted to disk diffusion test (3) at $30^{\circ} \mathrm{C}$ and minimal inhibitory concentration (MIC) using the microdilution test (6). MIC was determined for three antimicrobials to which A. eutrophus was resistant in standard disk diffusion test (data not shown). MICs obtained were 8,125 and $250 \mu \mathrm{g} / \mathrm{ml}$ for erythromycin, streptomycin and nitrofurantoin, respectively. Since MIC is based on growth or non-growth results, without any growth or accumulation kinetics data provided, experiments were performed to evaluate to what extent sub-MIC

\footnotetext{
* Corresponding author. Mailing address: Agrupamento de Biotecnologia, Divisão de Química, Instituto de Pesquisas Tecnológicas do Estado de São Paulo S.A. - IPT, Caixa Postal 0141, CEP 01064-970, São Paulo, SP, Brasil, Fax (+5511) 3767-4055, E-mail: lukneif@ipt.br
} 
concentrations would still modify the maximum specific growth rate $\left(\mu_{\max }\right)$ and also the specific P3HB accumulation rate $\left(\mu_{\mathrm{PHB}}\right)$. In growth experiments, glucose plus fructose $\left(5 \mathrm{~g} . \mathrm{l}^{-1} \mathrm{each}\right)$ and $\left(\mathrm{NH}_{4}\right)_{2} \mathrm{SO}_{4}\left(3{\mathrm{~g} .1^{-1}}^{-1}\right)$ were supplied in mineral salts medium containing two fold original concentration of phosphates and 1.5 fold $\mathrm{MgSO}_{4}(11)$. In accumulation experiments, a nitrogen free mineral salts medium containing glucose $\left(10\right.$ g..$\left.^{-1}\right)$ was tested. The antibiotics were added in concentrations 2,4 and 8 fold lower than the MICs. In growth experiments, samples were taken at every $2 \mathrm{~h}$ to analyse: optical density at $610 \mathrm{~nm}\left(\mathrm{OD}_{610}\right)$ (Spectronic Genesys 5 spectrophotometer) and $\mathrm{pH}$ (Mettler Delta $350 \mathrm{pHmeter}$ ). Values of $\mu_{\max }$ were calculated choosing by inspection the best points from the plot $\mathrm{LnOD}_{610}$ versus time and calculating the slope of the straight line using the minimum squares method as indicated in Fig. 1. In accumulation experiments, samples were taken at every $4 \mathrm{~h}$ to evaluate cellular dry biomass (7) and P3HB concentration (7). Values of $\mu_{\mathrm{PHB}}$ were obtained from the plot: ratio of $\mathrm{P} 3 \mathrm{HB}$ concentration by the average of residual biomass ( $\mathrm{X}_{\mathrm{r}}$, i.e, non-P3HB biomass) versus time.

Reference $\mu_{\max }$ of $A$. eutrophus on mineral medium with glucose plus fructose was $0.30 \pm 0.01 \mathrm{~h}^{-1}$ (average and standard deviation of 4 repetitions). A. eutrophus was resistant to nitrofurantoin in disk diffusion test but MIC results indicated that the growth would be inhibited at an approximate concentration of $250 \mu \mathrm{g} / \mathrm{ml}$. However, when submitted to 125 $\mu \mathrm{g} / \mathrm{ml}, \mu_{\max }$ decreased from 0.30 to $0.09 \mathrm{~h}^{-1}$, indicating that nitrofurantoin strongly affected $\mu_{\max }$ even at $50 \%$ of MIC. Even concentrations amounting 25 and $12.5 \%$ of MIC affected considerably $\mu_{\max }$ which reached 0.24 and $0.26 \mathrm{~h}^{-1}$, respectively. A reduction on antibiotic concentration from 125 to $31 \mu \mathrm{g} / \mathrm{ml}$ did not eliminate a prolonged lag phase (Fig.1), despite $\mu_{\max }$ have raised from 0.09 to $0.26 \mathrm{~h}^{-1}$. On the other hand, erythromycin did not affect bacterial $\mu_{\max }$ in the three concentrations tested since values obtained were between 0.29 $0.30 \mathrm{~h}^{-1}$ (plots not shown). Streptomycin was at an intermediate position and exerted a moderate effect on $\mu_{\max }$ in all sub-MIC concentrations tested. Although in presence of $50 \% \mathrm{MIC}, \mu_{\max }$ decreased to $0.25 \mathrm{~h}^{-1}$, this value was $0.29 \mathrm{~h}^{-1}$ when the other two concentrations were tested.

Results obtained indicate that a contaminant arising during growth phase should be tested against antibiotics at concentrations that maintained $\mu_{\max }$ of A. eutrophus between $0.29-0.31 \mathrm{~h}^{-1}$. Thus a sensitive contaminant could be eliminated without interfering in the growth of the main bacteria. The use of nitrofurantoin might be possible at $12.5 \%$ of MIC if no other alternative is available as it strongly affects the standard strain during growth phase. Therefore the application of conditions capable to keep A. eutrophus at a $\mu_{\max } \geq 0.29 \mathrm{~h}^{-1}$ are recommended in the control of sensitive contaminant bacteria.

The reference $\mu_{\mathrm{PHB}}$ for A. eutrophus in nitrogen free mineral medium, with $10 \mathrm{~g} / 1^{-1}$ of glucose without antibiotic (average of 4 repetitions) was $0.09 \pm 0.02 \mathrm{~g}_{\mathrm{PHB}} / \mathrm{g}_{\text {cells }} \cdot \mathrm{h}$. Nitrofurantoin did not modify $\mu_{\mathrm{PHB}}$ only when $12.5 \%$ of MIC was used $\left(\mu_{\mathrm{PHB}}=0.08\right.$ $\left.\mathrm{g}_{\text {PHB }} / \mathrm{g}_{\text {cells }} \cdot \mathrm{h}\right)$, being harmful to bacterial P3HB accumulation at higher concentrations. At $25 \% \mathrm{MIC}, \mu_{\mathrm{PHB}}$ was $0.05 \mathrm{~g}_{\mathrm{PHB}} / \mathrm{g}_{\text {cells }}$.h.

\section{Growth experiments}
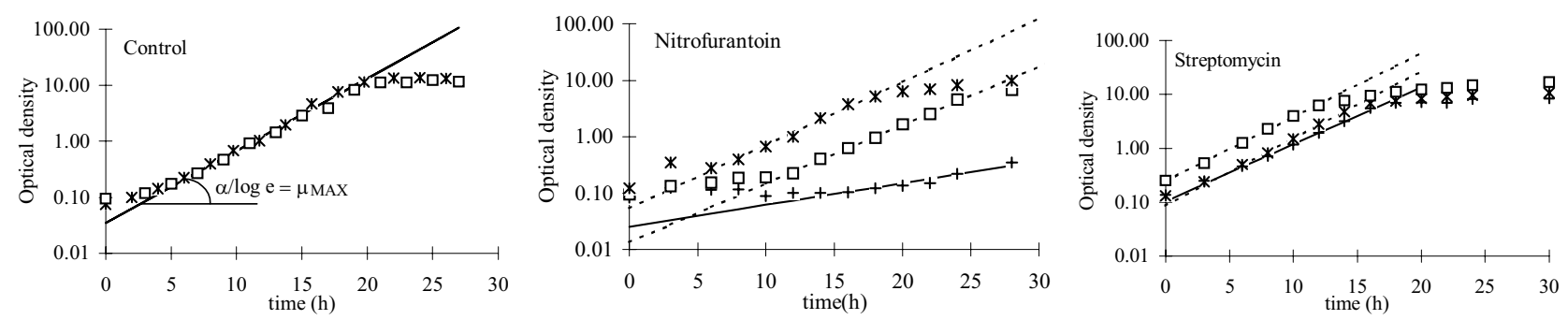

Accumulation experiments
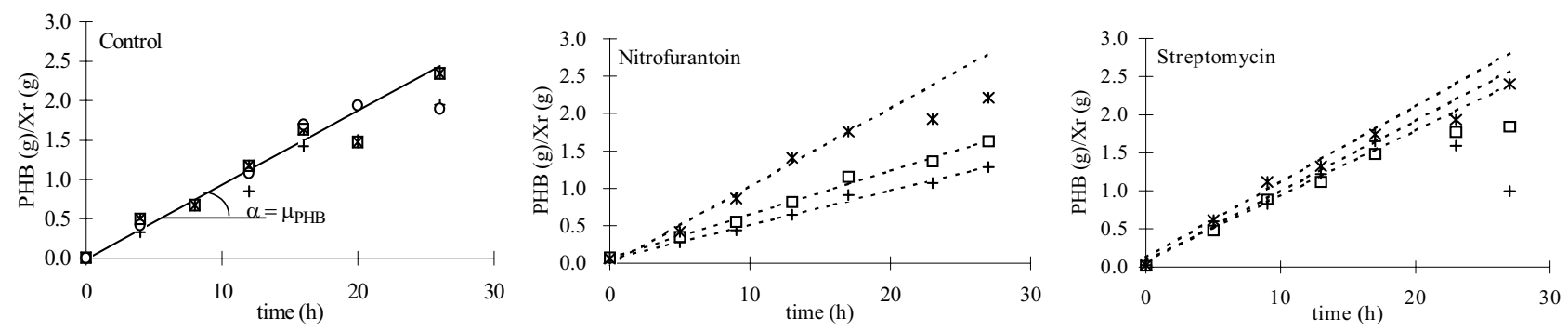

Figure 1. Results and plots used to calculate $\mu_{\max }$ and $\mu_{\mathrm{PHB}}$ of $A$. eutrophus without and with antimicrobials selected: erythromycin, streptomycin and nitrofurantoin at concentrations corresponding to (+) $50 \%$ MIC, ( $\square) 25 \%$ MIC and (*) $12.5 \%$ MIC. 
The most harmful effect was observed when $50 \%$ of MIC was applied reducing $\mu_{\mathrm{PHB}}$ to $0.04 \mathrm{~g}_{\mathrm{PHB}} / \mathrm{g}$ cells $\mathrm{h}$. Erythromycin and streptomycin did not affect bacterial $\mu_{\mathrm{PHB}}$, since values obtained were between 0.08 and $0.11 \mathrm{~g}_{\mathrm{PHB}} / \mathrm{g}_{\text {cells }} \cdot \mathrm{h}$. Nistatin effect was tested in similar experiments applying double and half of the concentration used to inhibit yeast contamination $\left(60 \mu \mathrm{g} \cdot \mathrm{ml}^{-1}\right)$ and did not affect $\mu_{\mathrm{PHB}}$ neither $\mu_{\max }$.

The successful control of bacterial contamination by antimicrobials in bacterial fermentative processes should take into account the susceptibility of both the contaminant and the microorganism responsible for the process. Since there are usually only slight differences between both organisms concerning to structure, morphology and physiology, the choice of antimicrobials for contamination control based on selective toxicity is difficult. This choice must first consider the susceptibility of the industrial microorganism.

In this work, a procedure is proposed to identify the antibacterials from different chemical groups plus the antimycotic nistatin that can be applied in the control of microbial contamination during $\mathrm{P} 3 \mathrm{HB}$ production by A. eutrophus. Once determined those antimicrobials to which the industrial microorganism is resistant, they should be tested against a contaminant detected in the fermentation process. In the case studied, amongst 3 antibacterials to which $A$. eutrophus was resistant, nitrofurantoin should be used carefully against contaminant since it expressively modifies bacterial $\mu_{\max }$ and $\mu_{\mathrm{PHB}}$ even at sub-MIC concentrations. Erythromycin and streptomycin did not affect $\mu_{\mathrm{PHB}}$ and could control a sensitive contaminant detected in the accumulation phase. It is important to remind that a decreasing in the value of $\mu_{\max }$ from 0.30 to 0.26 or $0.09 \mathrm{~h}^{-1}$ would represent an extension on the time required for the industrial fermentation process of about 15 and $70 \%$, respectively and could result in significant economical loss.

The disk diffusion test and MIC are useful tools to be applied as preliminary susceptibility determinations to select antimicrobials to control contamination in fermentative processes. Although MIC values can be used as reference, specific tests must be performed to evaluate the real influence of antimicrobials on the industrial strain under production situations to assure a safety handling of contamination if it occurs, avoiding economical loss.

This approach could be applied to processes of any fermentative product. In addition to the routine procedures to prevent contamination, a careful selection of the antimicrobial and concentrations that can be applied should be accomplished. A criterious evaluation about the scale application, environmental impacts and even the influence in the product obtained must be also taken into account.

\section{RESUMO}

\section{Procedimento para escolha de antimicrobianos como agentes de controle em fermentações por bactérias}

Avaliou-se o efeito de concentrações inferiores à mínima inibitória $(50,25$ e 12,5\% do MIC) de nitrofurantoína, estreptomicina e eritromicina sobre velocidade específica máxima de crescimento $\left(\mu_{\max }\right)$ e velocidade específica de acúmulo de polímero $\left(\mu_{\mathrm{PHB}}\right)$ em Alcaligenes eutrophus, considerada resistente a estes antimicrobianos. Nitrofurantoína modificou bastante $\mu_{\max }$, mesmo com 50\% MIC. Estreptomicina afetou moderadamente e eritromicina não afetou $\mu_{\max }$. Quanto à produção de polímero, nitrofurantoína alterou fortemente $\mu_{\mathrm{PHB}}$ quando se empregou 50\% MIC.

Palavras-chave: sensibilidade a antimicrobianos, MIC, PHB, Alcaligenes eutrophus, Ralstonia eutropha

\section{REFERENCES}

1. Anderson A.J., Dawes E.A. Occurrence, metabolism, metabolic role and industrial uses of bacterial polyhydroxyalkanoates. Microbiol. Rev., 54:450472, 1990

2. Aquarone, E.J. Penicillin and tetracycline as contamination control agents in alcoholic fermentation of sugar cane molasses. Appl. Microbiol., 8: 263-268, 1960

3. Bauer, A.W., Kirby, W.M.M., Scherris,J.C., Truck, M. Antibiotic susceptibility testing standardised single disk method. Am J Clin. Pathol., 45 (4): 493-496, 1966

4. Byrom, D. Industrial production of copolymer from Alcaligenes eutrophus. In: Dawes EA (ed.) Novel biodegradable microbial polymers. Kluwer, London, 1990, p. 113-117

5. Byrom, D. Production of poly- $\beta$-hydroxybutyrate and poly- $\beta$ hydroxyvalerate copolymers. FEMS Microbiol. Rev., 103: 247-250, 1992

6. Gavan, T.L., Town, M.A. A microdilution method for antibiotic susceptibility testing: an evaluation. Am J Clin. Pathol., 53:880-885, 1970

7. Gomez, J.G.C., Rodrigues, M.F.A, Alli, R.C.P., Torres, B.B., Bueno Netto, C.L., Oliveira, M.S.; Silva, L.F. Evaluation of soil Gram-negative bacteria yielding polyhydroxyalkanoic acids from carbohydrates and propionic acid. Appl. Microbiol. Biotechnol. 45, 785-791, 1996.

8. Holmes, P.A. Applications of PHB - a microbially produced biodegradable thermoplastic. Phys. Technol., 16:32-36, 1985

9. King, P.P. Biotechnology. An industrial view. J. Chem. Tech. Biotechnol., $32: 2-8,1982$

10. Melo Cruz, M.R., Vairo, M.L.R., Gambassi, D.M., Alterthum, F. Influência da penicilina $\mathrm{V}$-ácida no controle das infecções bacterianas na fermentação alcoólica. Rev Microbiol., 16:138-42, 1985

11. Ramsay, B.A., Lomaliza, K., Chavarie, C., Dube, B., Batille, P., Ramsay, J.A. Production of poly- $\beta$-hydroxybutyric-co- $\beta$-hydroxyvaleric acid. Appl Environ. Microbiol., 56:2093-2098, 1990 